\title{
パワーエレクトロニクスにおける実装技術の展望と現状
}

\section{Recent Progress and Prospect of Jisso Technology for Powerelectronics}

\author{
パワーエレクトロニクス研究会
}

\section{1. まえがき}

世界で国内総生産 (GDP) あたりの $\mathrm{CO}_{2}$ 排出ガス量は, 2015 年時点で 3.1 トンと 00 年より 0.7 トン, 約 2 割減と なった ${ }^{1)}$ 。これは再生可能エネルギ投資に加え, 新興国で 省エネ投資が拡大した効果とみられている。 $\mathrm{CO}_{2}$ 最大排出 国である中国では発電部門を石炭から太陽光など再生可能 エネルギなどに転換し，2040 年には石炭消費を現在から 40\% 削減する方針を出している。

一方，日本は実質 GDP 当たりのエネルギ消費量は世界を 大きく下回っておりアメリカと比べ約 2 分の 1 , 同じ非資 源国の韓国と比べても約 3 分の 1 の消費に抑えられてい る ${ }^{2)}$ 。エネルギ利用効率が非常に良い一方で, エネルギ需 要は拡大し 1973 年度に比べ 2015 年度では 1.2 倍のエネル ギ増となっている。

世界的にみると 2040 年には必要な電力需要は $70 \%$ 増加 すると見达まれており省エネルギ, 環境への関心がさらに 高まることが予想される。

これら背景を踏まえ，最新のパワーエレクトロニクス技 術を駆使した地球環境対策, 省エネルギ・高効率化が注目 されている。パワーエレクトロニクスは従来の産業機器, 鉄道車両などのモーターコントロール分野から, 近年では ハイブリッドカーや電気自動車での $\mathrm{CO}_{2}$ 削減, また太陽光, 風力発電などの新エネルギの電力変換分野に加え, 新たな 分野 (医療, 福祉ロボット) における適用が進んで来てい る。パワーエレクトロニクス装置では, 小型で高効率とい うだけでなく使いやすく壊れにくい, という視点からシス テム化, 使用環境の多様化が進んでくるものと予想される。

パワーエレクトロニクス実装技術は, このような方向性 の中で,

(1)高パワー密度化・小型化

（放熱技術，冷却技術，材料技術，封止技術）

(2)高効率化

（低インダクタンス技術，接合技術）

(3)システム化

(回路技術, センサ搭載技術)
に関しての技術革新が重要なポイントとなる。

本研究会では，これらの必要技術を確実に実現するため パワーエレクトロニクス適用分野の将来像からパワーエレ クトロニクス実装技術のロードマップを明らかにする研究 の場を提供，またロードマップ実現に必要な最新技術を共 有化し関連研究・関連産業技術の活性化に貢献すること目 的とし活動をおこなっている。

\section{2. パワーエレクトロニクス研究会における取組}

本研究会では 2015 年 1 月より, パワーエレクトロニクス に関連する研究会を開催，活発な意見交換をおこなってい る。本学会春季講演大会における, パワーエレクトロニク ス関連の発表件数の推移を図 1 に示す。発表件数からも 年々, パワーエレクトロニクスに関しての関心が高まって 来ている事が判る。研究会における主な内容としては, パ ワーエレクトロニクス装置の分解を行い, 構造, 実装技 術, 部品構成について調査し, 産業用インバータ, ハイブ リッド電気自動車インバータの分解を行いパワーエレクト ロニクスアプリケーションによる部品, 実装技術の比較を 実施した。パワーエレクトロニクスの基幹部品であるパ ワー半導体モジュールについても同様にパワーエレクトロ ニクスアプリケーション毎に，分解調查を実施し適用され ている実装技術，部品材料，回路設計について調査をおこ なった。

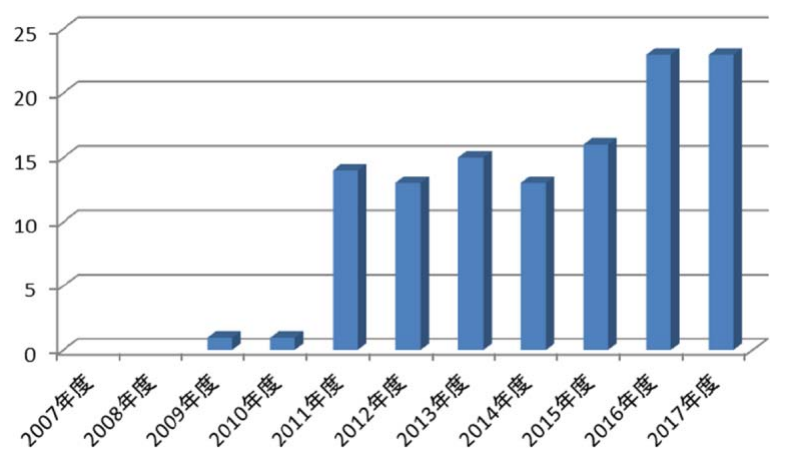

図 1. 春季講演大会でのパワーエレクトロニクス関連の発 表件数 
さらにパワーエレクトロニクスの適用分野, 構成分野に おける動向を明確化するため, 非公開研究会にて, イン バー夕, $\mathrm{SiC}, \mathrm{GaN}$ デバイス, キャパシタ, 電子部品実装 の動向について調査を実施した。

またエレクトロニクス実装学会春季講演大会, MES のパ ワーエレクトロニクス研究会のセッションにおいてパワー エレクトロニクス関連の第一人者に講演を依頼し，パワー エレクトロニクスアプリケーションから，材料技術までパ ワーエレクトロニクスサプライチェーン全体を見据えた議 論を実施した。

これらの議論にて特に関心が高かった項目についてはエ レクトロニクス実装学会誌 2017 年 11 月号の特集「パワー エレクトロニクスの動向」としてまとめている。

本稿では, これらの研究会活動で得られたパワーエレク トロニクスにおける実装技術の展望と現状について報告す る。

\section{3. パワーエレクトロニクスの現状}

\section{1 パワーエレクトロニクスの動向}

パワーエレクトロニクスシステムの主な課題は, トータ ルでの高効率化と二酸化炭素排出量の低減, 大規模基幹系 と分散電源との協調による高効率で安定な運用制御であ る ${ }^{3)}$ 。そのためパワーエレクトロニクス機器は, 従来のパ ワーエレクトロニクスコンポーネントから, 情報ネット ワークと統合され高機能な制御を含むパワーエレクトロニ クスシステムに変化する傾向がみられる。そのため, パ ワーエレクトロニクスを“つなぐ”技術開発が重要になっ てくる。パワーエレクトロニクス分野毎の動向 ${ }^{4)}$ を下記に 示す。

\section{1) 産業分野}

インバータが発生する損失の約 50〜 60\% はパワー半導体 で発生しており, パワー半導体の発生損失を低減できると 冷却系の小型化が可能となり, 装置全体として, さらなる 小型化が図れるとともに省エネルギ化に大きく寄与できる。

2) 情報分野

情報通信トラフィックの爆発的な増加に伴い, 情報通信 インフラ分野であるサーバ，ルー夕およびこれらが設置さ れるデータセンタなどの電力消費の増大が懸念されてい る。そのため Amazon や Facebook は, データセンタ用の電 力をまかなうため風力発電所を建設すると発表している ${ }^{5), 6) 。 ~}$

低損失で高周波化が可能なパワー半導体を用いた高効率 かつ高速応答な電源システムの実現により, IT 機器の電力 消費を大幅に削減することが可能となる。

\section{3) 民生分野}

家庭における電力消費の中ではエアコン, 冷蔵庫, 照明 器具, テレビの割合が大きい。この中で, 特にエアコンと 冷蔵庫においては, 低損失のパワー半導体を適用すること で家庭の消費電力を大幅に削減でき, 省エネルギ効果は大
きい。

4) 自動車分野

ハイブリッド車が小型車から大型車に適用されることに よって，インバー夕の容量は $100 \mathrm{~kW}$ を超える。インバー 夕が大容量化すると搭載場所が制約されるためインバータ の小型化が求められる。低損失パワー半導体の適用は, イ ンバータのパワー密度が高められ, 冷却に伴う部品体積を 小さくすることができる。さらに，インバータの損失低減 が直接燃費につながる。

モータ+インバータ効率は半導体素子のスイッチング周 波数を現状の約 $8 \mathrm{kHz}$ から約 $15 \mathrm{kHz}$ までを上げることで効 率が最大になるとされている ${ }^{7}$ 。現状 $(8 \mathrm{kHz})$ より $\mathrm{SiC}$ など を用い高周波数化が進むと予想される。

ガソリン車，ディーゼル車の禁止宣言により注目されて いるプラグインハイブリッド，電気自動車では，バッテ リイへの充電時間が課題となっている。より短時間での充 電を実現するため高電圧, 高周波の電力変換を行う方向に 動いている。

\section{5) 電鉄分野}

電鉄用インバータには，車両を駆動するための主変換装 置, 車両内の機器への電力供給に使われる補助電源装置が ある。主変換装置に使われるインバー夕には回路構成が簡 単な 2 レベルインバー夕, 高調波発生の少ない 3 レベルイ ンバータがある。ここでも低損失のパワー半導体の適用に より, さらなる小型・軽量化と低騒音化が可能となる。低 インダクタンス構造を採用したフル $\mathrm{SiC}$ 搭載のパワーモ ジュールも発表された。眓 2 に鉄道車両向け $\mathrm{SiC}$ 搭載パワー 半導体モジュールと駆動用主変換装置を示す。

次世代の東海道新幹線 $\mathrm{N} 700 \mathrm{~S}$ に $\mathrm{SiC}$ パワー半導体の搭載 が決まった。

鉄道車両は通常，自動車より 5 年早いロードマップとな るため, 電鉄分野への $\mathrm{SiC}$ 適用開始に伴い他分野にも $\mathrm{SiC}$ の普及が加速すると思われる。

6) 新エネルギ分野

太陽光発電は, 全世界のシステム導入量が 2010 年 $39 \mathrm{GW}$ に対し 16 年末で $300 \mathrm{GW}$ を超えるようになった ${ }^{8)}$ 。システ ム価格も 2010 年の約 6 ドルから現在では 1 ドルを目指して おり，新興国でも拡大が見込まれている。

太陽光発電には, 系統連携に PCS（パワーコンディショ
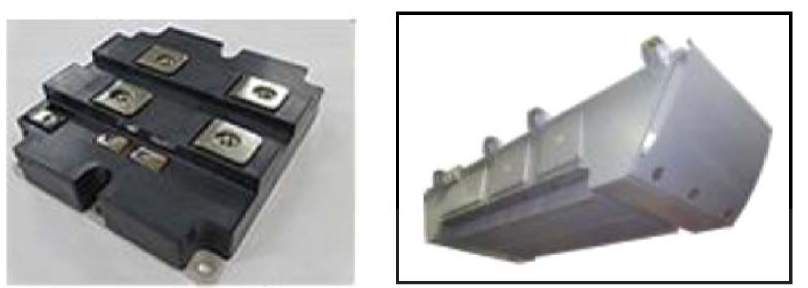

図 2. SiC 搭載パワーモジュール（左）と駆動用主変換装 置 $(\text { 右 })^{4)}$ 
ナー）が必要であるが，家庭用パワコンではパネルからの

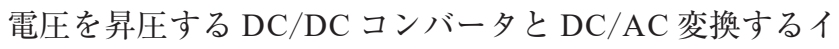
ンバータ, トランス, フィルターなどからなる。 PCS のト レンドは, 高効率化, 大容量化, 軽量化, 高電圧化であ り, 高効率化に対しては階調制御方式の回路の工夫などに より 97.5\%の高効率が得られている。低損失で高周波化が 可能なパワー半導体を用いることによりフィルター回路や 磁性部品の小型化が図れ, 最終的に損失低減につながる。

さらに発電効率を向上させる方法として分散型 PCS を採 用することで太陽光パネルへの影・方位・傾斜角のばらつ きに伴うロスを減らす手法が採用され始めておりパワエレ による貢献が期待される分野である。

7) 新規適用分野

(1)非接触給電

車載分野において, 排出ガス規制に対応するため 2020 年 以降に, PHEV (プラグインハイブリッド) モデルが多く 登場することが予想されている。EVと同様にPHEVにお いても自動車への充電システムが必要となる。現在の充電 システムでは充電ケーブルが重く, 今後の大電流／高速充 電には対応できない可能がある。現在の非接触給電システ ムでは変換効率の面で接触式に対し劣るが, $\mathrm{SiC}, \mathrm{GaN}$ な どの高周波動作可能なパワー半導体を用いることで高効率 化・小型化の実現が期待されている。

\section{(2)医療器分野}

重粒子線を用いたがん治療が注目を集めている。重粒子 を加速する加速器に用いているサイリス夕をIGBT パワー モジュールに切り替えることで, 肺がんなどに対しての重 粒子線治療をおこなうことが可能となった。さらに $\mathrm{SiC}$ パ ワーデバイスが適用することで冷却システムが小型化さ れ, 加速器の小型化が可能となる。現在, 日本に 15 ケ所し かない重粒子線治療拠点が, 加速器の小型化により一般病 院においても重粒子線がん治療が可能になることが期待さ れる。

\section{$3.2 \mathrm{SiC}, \mathrm{GaN}$ デバイスの現状}

現在， $\mathrm{SiC}, \mathrm{GaN}$ を中に WBG デバイスがその性能の高 さから次世代デバイスとして期待されている。表 1 に $\mathrm{Si}$, $\mathrm{SiC}$ および $\mathrm{GaN}$ デバイス用半導体材料の特性を示す。 $\mathrm{SiC}$ や $\mathrm{GaN}$ などの $\mathrm{WBG}$ 半導体材料の特徴は, 最大電界強度が 高く，特に $\mathrm{SiC}$ は熱伝導率が高いことである。

最大電界強度が 1 桁高いためべース層を薄くでき，バイ ポーラデバイスである IGBT や pn ダイオードに比べ高速ス イッチングが可能なユニポーラデバイスの MOSFET や ショットキダイオードの実現が可能である。また，バンド ギャップが約 3 倍と広いため, 高温で動作可能という長所 も持ち合わせている。図 3 に示すように今後の広範囲なパ ワエレ分野での普及が期待されている ${ }^{9)} 。$

多くの優位性を持つ $\mathrm{SiC}$ デバイスや $\mathrm{GaN}$ デバイスではあ るが, 現状の課題としては, 大口径化, 低欠陷化, 低コス
表 1. 半導体材料の特性

\begin{tabular}{|c|c|c|c|c|}
\hline 項 & $\mathrm{Si}$ & $4 \mathrm{H}-\mathrm{SiC}$ & $\mathrm{GaN}$ & $\mathrm{Ga}_{2} \mathrm{O}_{3}$ \\
\hline バンドギャップ (eV) & 1.12 & 3.26 & 3.39 & $4.8-4.9$ \\
\hline 電子移動度 $\left(\mathrm{cm}^{2} / \mathrm{Vs}\right)$ & 1,500 & 1,000 & 900 & 300 (推定) \\
\hline 正孔移動度 $\left(\mathrm{cm}^{2} / \mathrm{Vs}\right)$ & 500 & 120 & 150 & - \\
\hline チャネル移動度 $\left(\mathrm{cm}^{2} / \mathrm{Vs}\right)$ & 500 & 140 & 1,500 & - \\
\hline 最大電界強度 (MV/cm) & 0.3 & 3 & 3.3 & 8 (推定） \\
\hline 最大電界強度 Si 比 & 1 & 10 & 11 & 27 \\
\hline 熱伝導率 $(\mathrm{W} / \mathrm{cm} \cdot \mathrm{K})$ & 1.5 & 4.9 & 2 & 0.23 \\
\hline 熱伝導率 Si 比 & 1 & 3.3 & 1.3 & 0.2 \\
\hline 飽和速度 $(\mathrm{cm} / \mathrm{s})$ & $1.0 \mathrm{E}+07$ & $2.2 \mathrm{E}+07$ & $2.7 \mathrm{E}+07$ & - \\
\hline 誘電率 & 11.8 & 9.7 & 9 & 10 \\
\hline
\end{tabular}

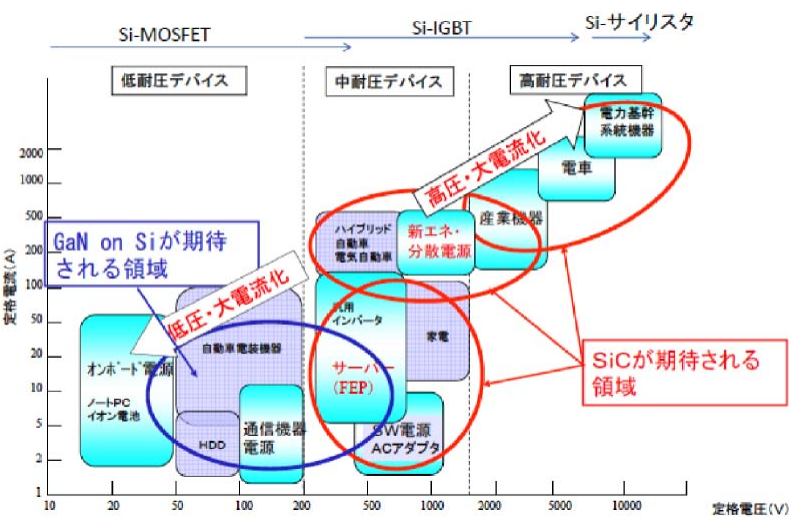

図 3. SiC/GaN デバイスの対象領域 ${ }^{9)}$

ト化などが挙げられ，高品質ウェハおよびエピ製造技術の 開発が精力的に進められている。また，デバイス自身の課 題としては, 特性の安定化技術が挙げられ，ゲート耐圧の 長期安定化技術や，しきい值電圧制御技術などがある。

これらの課題に対し, 損失改善は, $\mathrm{SiC}$ デバイス構造が, 従来のプレーナー型からトレンチ構造の開発が進み RonA の低オン化が進んでいる ${ }^{10)}$ 。さらに $\mathrm{SiC}$ デバイスに短絡電

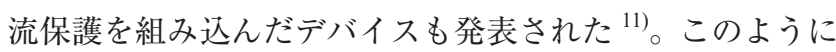
$\mathrm{SiC}$ デバイスの実市場要求に耐えられるものが実現されて きている。

\section{3 パワー半導体モジュールの技術動向}

パワー半導体デバイスは, そのパッケージ形態より 1) ディスクリートタイプ，2) モジュールタイプに大きく分類 することができる。ディスクリートタイプは, 半導体素子 (MOSFET, IGBT, SiCなど）を金属フレーム（リードフ レーム）に固着し，ワイヤボンディングなどの結線後，樹 脂封止するパッケージ構造体である。これに対して，モ ジュールタイプは, 複数の半導体素子（IGBT, $\mathrm{SiC}$ など） が固着された絶縁基板を金属放熱板上に固着し，ワイヤボ ンディングなどで結線後, 樹脂封止するパッケージ構造体 であり，主にモー夕制御用のインバー夕装置に組み込まれ る。

パワー半導体モジュールのパッケージ技術は，必然的に そのアプリケーションの動向および要求に連動して進化し てきた。具体的には，パワーエレクトロニクス装置（イン バータ）の高効率化と小型化を達成するためのモジュール 
パッケージ技術が主な開発方向となっている。2017 年度の 学会発表・公開研究会での発表から, 各技術動向を以下に 述べる。

(1)高周波数対応：SiC-MOSFET の高速スイッチング／高周 波数での動作を活かすために, サージ電圧を低減する必 要がある。そのためパワーモジュールの低インダクタン ス化が進んでいる。低インダクタンス化は, 回路 PNの 狭ピッチ配線 ${ }^{4)}$ など, パワーモジュール内部の回路配線 位置を工夫することにより図られている ${ }^{12) 。 ~}$

(2)高温動作化：パワーモジュールの連続動作温度 $150^{\circ} \mathrm{C}$ か ら $175^{\circ} \mathrm{C}$ に高温化。高温化に伴い $\mathrm{Tj} \mathrm{P} / \mathrm{C}$ などの信頼性寿 命低下が課題。信頼性寿命を確保するため, はんだ材の 高強度化や $\mathrm{Ag}, \mathrm{Cu}$ シンター材の焼結プロセス簡易化に 向け無加圧化の開発が進んでいる。

$\mathrm{SiC}$ では動作可能温度が $\mathrm{Si}$ より上昇するためより顕著 に高温動作化の影響がでると予想される。

また従来では許容範囲であった接合部ボイドが, チッ プ低損失化に伴う薄化により影響が大きくなることが 判ってきている ${ }^{13), 14)}$ 。高品質な接合実装技術が今後必要 となることが予想され, 接合部のボイド発生要因メカニ ズム分析などにも注目が集まっている。実装技術は製品 の使われ方に依存するようになってきており製品設計の 初期段階からの連携が必要となっている ${ }^{15)}$

また GaNでは，熱によるゲート電圧閾值の変動するこ とで誤動作が発生する。これに対しモジュールの回路設 計による対策が報告されている ${ }^{16)}$ 。

(3)高電流密度化：Si チップの低損失化や $\mathrm{SiC}$ チップ採用に より電流密度が上昇。高電流密度を実現する回路配線技 術が必要となってきている。そのため従来の Al ワイヤボ ンディング配線から， $\mathrm{Al}$ リボン接合， $\mathrm{Cu}$ ワイヤ, $\mathrm{Cu} / \mathrm{Al}$

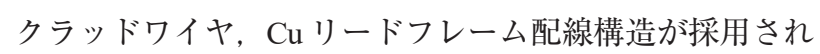
大電力／高電流密度化に対応している。

(4)高耐圧：一般に高耐圧製品は, インフラや電鉄向けに採 用されることが多く高耐圧負荷, 動作時に扔ける安定し た製品寿命品質が求められる。そのためパワーモジュー ル構造に扔ける放熱板として一般的な $\mathrm{Cu}$ ベースでなく $\mathrm{A} 1 \mathrm{SiC}$ ベースが採用されていた。新素材の放熱材料とし て $\mathrm{AlSiC}$ と熱膨張係数が同じで接合層に発生する応力が 小さく, 放熱性能が高い $\mathrm{MgSiC}$ を用いたパワーモジュー ル構造が採用されつつある。

(5)絶縁技術：一般産業用途向けパワーモジュールは耐電圧 $600 \mathrm{~V} \sim 1,200 \mathrm{~V}$ にて使用されている。そのため従来はセ ラミックス絶縁基板を適用していた。樹脂絶縁基板の熱 伝導率, 温度サイクル耐量が向上したため, $1,700 \mathrm{~V}$ まで 保証する樹脂絶縁基板を適用したパワーモジュール 17),18) が開発されている。

\section{4 各国における研究動向 ${ }^{4}$}

$\mathrm{SiC}$ デバイスの普及に押いて，材料，デバイス，実装抒
よびアプリケーションの各分野の包括的な研究開発の推進 が必要である。

ヨーロッパ：SPEEDは，大学などの学術研究機関とパ ワーデバイスおよびパワエレシステムメーカにより構成（8 力国が参加）され，EUなどが資金面でサポート。ECPE は, $\mathrm{SiC}$ デバイスの適用と超低損失なパワエレの包括的な 開発を行い, パワエレ分野の主要企業で構成され，バイエ ルン州政府と EU がサポート。

アメリカ：Power America は, 大学とパワエレ・デバイス 関連企業で構成されDOE（アメリカエネルギー省）などが サポート。NY-PEMC は，ニューヨーク州と民間業が出資 し設立。100 社以上の企業が参加。

このように，欧米では産学連携による緊密な研究開発体 制が構築されている。

日本：「エネルギー基本計画」「日本再興戦略 2016」, 「科学イノベーション総合戦略 2015」など, 各種の閣議決 定文章にてパワエレ関連の技術開発が重要な位置づけであ ることが示されている。SIP「戦略的イノベーション創造プ ログラム」やNEDO 助成事業「低炭素社会を実現する次世 代パワーエレクトロニクスプロジェクト」の中で WBG デ バイス抒よび WBG デバイスを適用した応用装置の研究開 発・実用化が精力的に取り組まれている。

\section{4. まとめ}

パワーエレクトロニクス分野に打けるパワー半導体の適 用分野は, 従来のモーターコントロールから, 電力変換分 野へと広がり, 初期コス卜重視から効率重視に変化してい る。そのため, パワーエレクトロニクスシステムを含めた トータル設計が必要となり, パワー半導体は高効率動作に 対応した構造が求められてきている。

さらにパワーエレクトロニクス機器を構成する周辺部品 においても高温, 高耐圧, 高速スイッチングに対応に向け た開発が加速している。

従来の Si から, 高温, 高耐圧, 高速スイッチング動作が 可能な $\mathrm{SiC}$ や $\mathrm{GaN}$ 半導体の出現, 高温動作に耐えうる新規 材料開発・適用が進みパワー半導体の特性, ひいてはパ ワーエレクトロニクスの性能を左右することから実装技術 の重要性が増す事が予想される。

(2017.11.30- 受理)

\section{文献}

1) IEA: “World Energy Outlook 2015," https://www.iea.org/

2）経済産業省資源エネルギー庁：“平成 28 年度エネルギーに 関する年次報告,”エネルギー白書, 2017

3）富士経済：“2015 年版 次世代パワーデバイス\&パワエレ 関連機器市場の現状と将来展望, ” p. 105

4）高橋良和, 両角 朗, 西村芳孝: “パワーエレクトロニクス を支えるパワー半導体モジュール技術の最新動向, 
MES2016 予稿集, pp. 15-22

5) Amazon Press Release, $16^{\text {th }}$ Sept 2016, https://www.amazon. $\mathrm{com} / \mathrm{p} /$ feature $/ \mathrm{ps} 9 \mathrm{c} 2 \mathrm{vfu} 7 \mathrm{fcm} 4 \mathrm{t} 6$

6) Facebook news room, $24^{\text {th }}$ Jan 2016 , http://newsroom.fb.com/ news/2016/01/county-meath/

7) 山本真義 : “ $\mathrm{SiC} / \mathrm{GaN}$ を中とした自動車用パワーエレクト ロニクスの最新技術動向, ” エレクトロニクス実装学会第二 回パワエレ研究会公開研究会予稿集, 2017

8) 市川幸美：“太陽光発電と高効率太陽電池技術, ”エレクト ロニクス実装学会第二回パワエレ研究会公開研究会予稿 集, 2017

9) 岩室憲幸：“新材料パワー半導体デバイスの最新技術動向 $(\mathrm{SiC}, \mathrm{GaN}), ”$ エレクトロニクス実装学会第二回パワエレ研 究会公開研究会予稿集，2017

10) D. Heer, D. Domes, and D. Peters: "Switching Performance of a 1,200 V SiC-Trench-MOSFET in a Low-Power Module," Proceeding PCIM Euro2016, pp. 53-59

11) E. Wiesner, et al.: "Advanced Performance for large Current Full SiC-Modules," Proceeding PCIM Euro2016, pp. 48-52

12) D. Kawase, K. Nagashima, T. Hirayama, K. Azuma, and S. Hayakawa: "NHPD2 (Next High Power Density Dual) with Next Generation Chip Suitable for Low Internal Inductance Package," Proceeding PCIM Euro2016, pp. 348-354

13）難波明博, 中津欣也, 西原淳夫, 大西正巳 : “次世代高出力 密度電動コンポーネント技術, ”エレクトロニクス実装学会
誌, Vol. 19, No. 5, pp. 321-324, 2016

14) 藤野純司, 坂本創一, 柳本辰則, 巽 裕章, 増森俊二 : “パ ワー半導体の高温動作を可能とするアセンブリ技術, MES2016 予稿集, pp. 155-158

15）神谷有弘：“車載パワーデバイスの放熱・実装技術動向,” エレクトロニクス実装学会第二回パワエレ研究会公開研究 会予稿集，2017

16) H. Umegami, H. Ishibashi, K. Nanamori, F. Hattori, and M. Yamamoto: "Basic Analysis of False Turn-on Phenomenon of Power Semiconductor Devices with Parasitic Inductances," IET Electronics Letters, Vol. 52, Issue 13, pp. 1158-1160, 2016

17) S. Asada, S. Kondo, Y. Kaji, and H. Yoshida: "Resin Encapsulation Combined with Insulated Metal Baseplate for Improving Power Module Reliability,” Proceeding PCIM Euro2016, pp. 326-330

18) A 1,700 V-IGBT module and IPM with new insulated metal baseplate (IMB) featuring enhanced Isolation Properties and Thermal Conductivity, Proceeding PCIM Euro2016, pp. 326-330

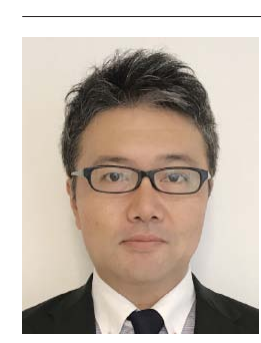

西村芳孝（にしむら よしたか）

著者紹介

富士電機株式会社 電子デバイス事業本部 開発 統括部 パッケージ開発部

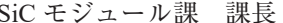

2000 年名古屋工業大学大学院修士課程修了。同年 富士電機株式会社に入社。開発部に所属しパワー 半導体モジュールのパッケージ実装技術開発に従 事。

エレクトロニクス実装学会パワーエレクトロニク 不研究会主查。工学博士 